Taple 1-A. Distribution of Maintenance Expenditures for Fiscal YiAR ENDING SEPTEMBER 30, 1928

\begin{tabular}{|c|c|c|c|c|c|c|}
\hline \multirow{2}{*}{ TYPES OF SUREAcE } & \multirow{2}{*}{$\begin{array}{l}\text { Miles } \\
\text { on which } \\
\text { Expend- } \\
\text { iture is } \\
\text { based }\end{array}$} & \multicolumn{5}{|c|}{ EXPENDED ON } \\
\hline & & Surface & Roadbed & Structures & $\begin{array}{c}\text { Snow } \\
\text { Removal }\end{array}$ & Total \\
\hline 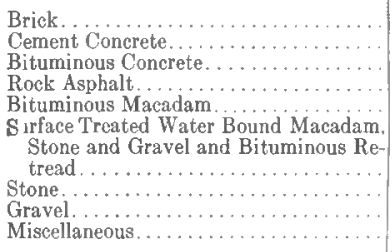 & $\begin{array}{r}61.18 \\
1,148.18 \\
22.72 \\
11.95 \\
149.83 \\
\\
131.41 \\
710.60 \\
1,072.90 \\
1,263.59 \\
\end{array}$ & $\begin{array}{r}215.20 \\
72.40 \\
201.50 \\
89.80 \\
336.10\end{array}$ & $\begin{array}{r}\$ 88.90 \\
128.40 \\
86.70 \\
121.50 \\
103.20\end{array}$ & $\begin{array}{r}\$ 3.00 \\
5.50 \\
19.30 \\
20.00 \\
6.30\end{array}$ & $\begin{array}{r}\$ 7.60 \\
10.40 \\
5.40 \\
.20 \\
8.60\end{array}$ & $\begin{array}{r}\$ 294.70 \\
216.70 \\
312.90 \\
231.50 \\
454.20\end{array}$ \\
\hline All Types.... . & $4,572.36$ & $\$ 147.80$ & $\$ 76.60$ & $\$ 11.80$ & $\$ 5.65$ & $\$ 541.80$ \\
\hline
\end{tabular}

\title{
KEEPING THE RECORDS STRAIGHT
}

By Lawrence F. Orr, State Examiner, Indiana State Board of Accounts

Editor's Note:-Mr. Orr was unable to attend the Road School due to pressure of official business. At our request he very kindly supplied answers to the following questions submitted by local road and street officials.

In answering inquiries and making examinations of accounts, we realize that an official may desire at times to undertake to do something for the benefit of the municipality, which the law prevents, and that in his desires to do so he is not guided by any selfish motives whatever. The only safe course, however, is to follow the law. As public officials, we can not do the things we can as individuals. Public officials can only exercise the powers and duties granted by statute. As individuals, the statutes provide what we can not do.

Hence, in the answers which we have given to these inquiries we have considered the law first and proper accounting which applies in consideration of the statutes.

Our department does not desire to be in a position of administering for public officials. We are an examining department, a department of public service. We are endeavoring to assist taxpayers and public officials throughout the state in the matter of obtaining good and efficient government within well defined financial limitations in order that the best results may be obtained without extravagance and waste of public funds. We believe we are in a position to render such services and we offer our department as one of service to the public. 
Question No. 1. Will the County Surveyor be required to charge the County Highway Superintendent for measuring county gravel piles and then turn the fee back to the County Treasurer?

Answer. Cost of measuring county gravel piles would be an expense against the free gravel road repair fund. The County Surveyor generally is paid on a salary basis from the county's general fund. Since the County Revenue Fund and the Free Gravel Road Repair Fund are raised from the same taxing unit, there would be nothing gained by having the County Surveyor charge the free gravel road repair fund for such services as he would have to pay the same over to the county's general fund.

Question No. 2. In doing the necessary engineering work for cleaning out drainage ditches should the work be charged to the Township Trustee, paid to the County Surveyor and he in turn pay it to the County Auditor or should the work be done without charge to the Township Trustee, considering that this is a part of the surveyor's duties and included in his salary? Or again, should this be considered as private work outside the surveyor's regular duties for which the Trustee should be charged the old rate of $\$ 10.00$ per mile, permitting the Surveyor to make any profit therein after paying his costs of having the work done?

Answer. If the County Surveyor performs services for the township in cleaning out drains, such services are not private services. The ditch laws provide for the surveyor to do this work in certain instances and that the county should pay him for the same. Hence there would be no charge against the township under the allotment law. If assessments are levied, the county should be reimbursed from same at not to exceed ten dollars per mile.

Question No. 3. Is it legal for the County Surveyor to do outside private work in cities, for instance, providing he has time available and charging for same at a rate he deems reasonable, the profits to be his over and above his regular salary?

Answer. Where the Surveyor is employed on an annual salary by the county and would do private work during the hours of the day that belonged to the county, he should pay any fees for such private work into the county treasury. However, if such work were done after hours, it would seem that he could hold the fee. The county is entitled to eight hours per day of his time. Where the surveyor is not on a salary basis he could keep such fees for private work, if the same did not conflict with the days he had worked for the county.

Question No. 4. When a county surveyor goes out of office is he legally entitled to the highway drainage work started 
under his term of office or should this all be turned over to the incoming surveyor?

Answer. When the county surveyor retires from office, all his work on which he may then be engaged should be turned over to his successor.

Question No. 5. Is the county highway superintendent responsible for the maintenance of bridges on county roads built under the three mile road law where the bridge is located inside the city limits? This seems to be a debatable question as to whether or not the county or the city is responsible for the bridge.

Answer. If a bridge is built as part of highway construction coming under the provisions of the three mile gravel road law, and such road runs through an incorporated city, the city would keep up the road and bridge maintenance and under the law would charge the county with the cost of same, filing itemized claims against the county for service and material.

Question No. 6. Please explain the law relative to the ownership of gravel in stream beds. In some cases this is claimed by the property owners on each side of the stream and in other cases the county officials claim that the gravel can be taken by them without cost.

Answer. The bed of a stream which has been declared navigable is the property of the government or the state, as the case may be. On streams not navigable the bed of the stream belongs to the abutting property owners.

Question No. 7. In some counties the highway superintendents are constructing small bridges and culverts with their own forces instead of having the work let by contract. In most cases this results in a saving to the taxpayers but some have raised the objection that the practice is illegal. Please give your opinion on this matter.

Answer. The county highway superintendent has general charge of the expenditure of free gravel road funds in the repair of roads and bridges. If the repairs on a bridge on a county gravel road shall cost less than fifty dollars $(\$ 50.00)$, the superintendent has jurisdiction to make the repairs without consulting the Board of Commissioners. If the repairs shall cost more than fifty dollars $(\$ 50.00)$, he should be directed by the Board of Commissioners to make the repairs. When such repairs are made as above mentioned, the cost of the same is to be paid from the county gravel road repair fund. If the repairs shall cost more than one hundred dollars $(\$ 100.00)$, the repairs must be made in the manner provided by law; that is, plans and specifications shall be prepared and the contract shall be let upon competitive bidding, by the Board of Commissioners, in which case the cost of repairs should be paid out of county revenue. Appropriations for bridge repairs from county revenue must be specific and expenditures can only be paid for from appropriation for the 
particular bridge for which such appropriation was made by the county council. (Sec. 7755, Burns' R. S. 1914; Sec. 8507, Burns' R. S. 1926.)

There is no authority for an appropriation from county revenue for general bridge repairs. Said repairs should be paid for from the gravel road repair fund under the supervision of the county highway superintendent.

Question No. 8. In our county we are cooperating with township trustees in the improvement of township roads. The road in question is surveyed and staked by our county surveyor, the grading work is done by the county equipment and men to standard cross sections and then the township trustee pays for hauling on the road metal to county specifications. This is being done from a half to a third cheaper than where contracts are let, thereby saving the taxpayers money, yet some have raised the point that it can not be done legally. Please give your opinion on this matter.

Answer. The township should pay the county for any equipment or services furnished in such grading if the same is done at the expense of the free gravel road repair fund. This fund applies to the repair of county-owned highways. However, since the gasoline tax, under the provisions of the law pertaining to same, may be used by the county commissioners for construction and repair of any public highway in the county, such fund may be used without reimbursement for the purpose you have mentioned. Under the law, the proceeds of the gasoline tax distributed to counties should be carried as a separate and distinct fund.

Question No. 9. In most counties it is necessary to have clerical help to take care of office work and answer phone calls. This relieves the superintendent and permits him to spend more time on the road maintenance work. How can a stenographer be legally employed in a county highway superintendent's office? In some cases it is done by increasing the superintendent's salary so much per day, the superintendent paying this increase to his stenographer. In other counties the stenographer is listed as an assistant highway superintendent and paid accordingly. Please advise as to whether or not these proceedings are legal.

Answer. The statutes do not provide that the county highway superintendent may employ clerical help at the expense of the county. This should be paid by the superintendent personally as his per diem is fixed by the board of county commissioners.

Question No. 10. Is it legal to purchase gravel without advertising for bids? In many cases a saving to the taxpayer can be effected by this procedure, although some objection is raised to its legality.

Answer. Gravel may only be purchased according to law by advertising for bids and letting of contract therefor. 